\title{
Transformative Adaptations for Health Impacts of Climate Change in Burkina Faso and Kenya
}

\author{
Edmund Yeboah, Aditi Bunker, Peter Dambach, Isabel Mank, \\ Raïssa Sorgho, Ali Sié, Stephen Munga, Till Bärnighausen, and \\ Ina Danquah
}

\section{Contents}

Introduction: Proposed Adaptation Strategies for Climate Change Impacts in Two Exemplar

Regions of Sub-Saharan Africa ...................................... 2486

Strategy 1: Agro-Biodiversification and Nutrition Intervention in Rural Burkina Faso

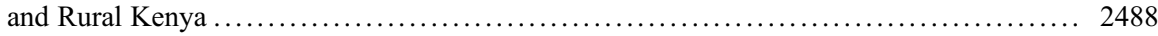

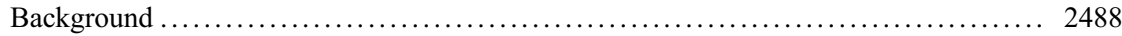

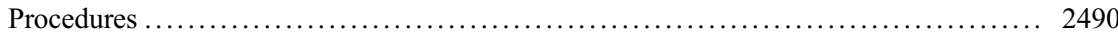

This chapter was previously published non-open access with exclusive rights reserved by the Publisher. It has been changed retrospectively to open access under a CC BY 4.0 license and the copyright holder is "The Author(s)". For further details, please see the license information at the end of the chapter.

E. Yeboah · A. Bunker · P. Dambach $\cdot$ I. Mank $\cdot$ R. Sorgho

Heidelberg Institute of Global Health (HIGH), Heidelberg University, Heidelberg, Germany e-mail: edmund.yeboah@uni-heidelberg.de; aditi.bunker@uni-heidelberg.de; isabel.mank@uniheidelberg.de; raissa.sorgho@uni-heidelberg.de

A. Sié

Centre de Recherche en Santé de Nouna (CRSN), Nouna, Burkina Faso

S. Munga

Centre for Global Health Research (CGHR) at the Kenya Medical Research Institute (KEMRI), Kisumu, Kenya

T. Bärnighausen

Heidelberg Institute of Global Health (HIGH), Heidelberg University, Heidelberg, Germany

Department of Global Health and Population, Harvard T. H. Chan School of Public Health, Boston, MA, USA

Africa Health Research Institute (AHRI), Durban/Mtubatuba, South Africa e-mail: till.baernighausen@uni-heidelberg.de

I. Danquah $(\bowtie)$

Heidelberg Institute of Global Health (HIGH), Heidelberg University, Heidelberg, Germany

German Institute of Human Nutrition Potsdam-Rehbruecke (DIfE), Nuthetal, Germany

e-mail: ina.danquah@uni-heidelberg.de 
Strategy 2: Cool Roofs to Improve Human Health, Environmental and Economic Outcomes

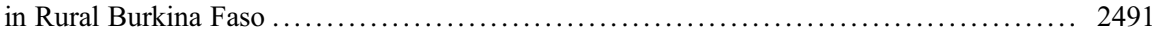

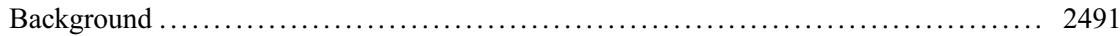

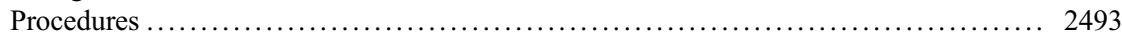

Strategy 3: Index-Based Weather Insurance in Rural Burkina Faso ................... 2493

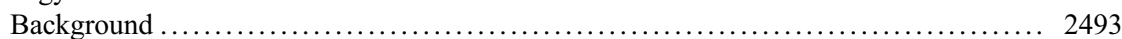

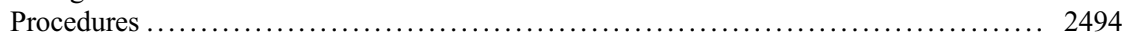

Strategy 4: Larviciding Against Malaria Vectors in Rural Burkina Faso ............... 2495

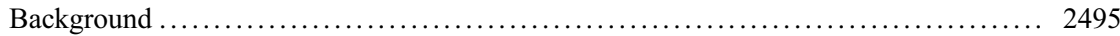

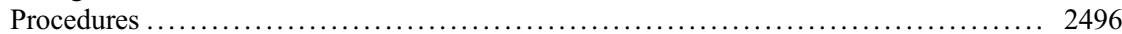

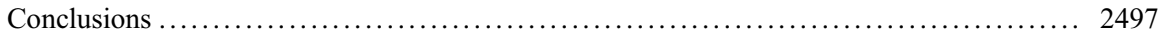

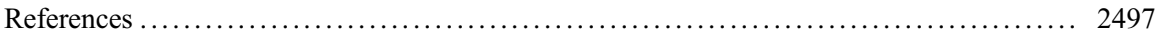

\section{Abstract}

Climate change strongly affects the health of sub-Saharan African populations. Effective adaptation strategies are required in order to enhance their limited adaptive capacities. The DFG-funded Research Unit (RU) "Climate change and health in sub-Saharan Africa" unites nine research institutions from Burkina Faso, Kenya, Germany, and Switzerland that will design, implement, and evaluate four different adaptation projects in these two African countries from 2020 until 2022.

First, the effectiveness of an agro-biodiversification and nutrition program will be established for the reduction of child undernutrition of climate-sensitive nutrients in rural Burkina Faso and Kenya. Two respective cluster-randomized controlled trials (cRCT) will be conducted, each consisting of $2 \times 600$ children. Second, another cRCT will be conducted among $2 \times 300$ households in rural Burkina Faso to investigate how sunlight-reflecting cool-roof coatings affect human health outcomes, including cardiovascular and heat-related outcomes. Further outcomes comprise indoor temperature, carbon footprint, and productivity. Third, an index-based weather insurance (IBWI) will be introduced in rural Burkina Faso. The effects of IBWI on childhood nutritional status, dietary behavior, and healthcare seeking will be determined in $2 \times 20$ villages. Fourth, microbial larviciding has been evaluated as a promising environmental control for malaria vectors in Burkina Faso. Here, the interactions between climatic factors and the effectiveness of the intervention will be tested using spatiotemporal models.

\section{Keywords}

Climate change $\cdot$ Sub-Saharan Africa $\cdot$ Adaptations $\cdot$ Undernutrition $\cdot$ Heatstress $\cdot$ Malaria

\section{Introduction: Proposed Adaptation Strategies for Climate Change Impacts in Two Exemplar Regions of Sub-Saharan Africa}

Climate change constitutes one of the biggest threats and opportunities to global health (Costello et al. 2009; Watts et al. 2015). The World Health Organization (WHO) estimates that between 2030 and 2050, climate change will cause 
approximately 250,000 additional deaths/year, with an increasing trend (WHO 2014). Indeed, global warming, weather instability, and weather extremes have emerged as major risk factors for global health acting on their own or modifying the effect of the wide array of the immediate and intermediate determinants of health. The recent report by the International Panel on Climate Change (IPCC) has concluded that climate change is expected to exacerbate a wide range of health problems, including undernutrition, vector-borne diseases, and noncommunicable diseases (IPCC 2017; Woodward et al. 2014). The report further points to the heatmediated productivity losses, not least in agricultural production in low-income settings (Kjellstrom et al. 2017). While the causes, impacts, and mitigation efforts of climate change truly act globally, efficient and effective adaptation strategies require local solutions. This is particularly true for sub-Saharan Africa, where climate change impacts on health are felt strongest because the populations there exhibit the least adaptive capacity.

Autonomous and planned adaptations will be necessary to meet the challenges of common smallholder subsistence systems in sub-Saharan Africa (IAASTD 2009). Small-scale subsistence farmers are defined as rural households with agriculturalbased access (max. 2 ha) to essential resources for survival (Grace et al. 2012). Proposed adaptation strategies generally refer to risk management or production enhancement, and include:

- Altering the timing or the location of cropping activities and the diversification of agriculture (Constanzo and Bàrberi 2013)

- Increasing the access to financial and technological resources that facilitate adaptation to climate change (Bizikova et al. 2009)

- Risk protection by index-based weather insurance (IBWI) as one option of market-based risk management mechanisms (Leblois and Quirion 2013)

- Novel methods of vector control to overcome drug resistance, changes in vectorbiting behavior, and altered vector species (Tusting et al. 2013)

Herein, four specific adaptation strategies are described that will be designed, implemented, and evaluated over the next 3 years (2020-2022) within the framework of the Research Unit (RU) "Climate Change and Health in sub-Saharan Africa," funded by the German Research Foundation (DFG). The RU builds on previous collaborations and existing research infrastructure within the Health and Demographic Surveillance Systems (HDSS) in Nouna (Burkina Faso) and Kisumu (Kenya). The locations and the characteristics of the two HDSS sites are presented in Fig. 1 and Table 1, respectively.

According to the gross domestic product (GDP) per capita, Burkina Faso is one of the poorest countries in the world, whereas Kenya ranks among the lower-middleincome countries (World Bank 2018). The HDSS sites Nouna and Kisumu have been established in the early 1990s; the Kisumu area is more densely populated than the Nouna site. Climate-wise, these two HDSS locations differ: Nouna experiences one rainy season per year with excessive rainfalls in August and high temperatures during the dry season; Kisumu has two rainy seasons and experiences lower 


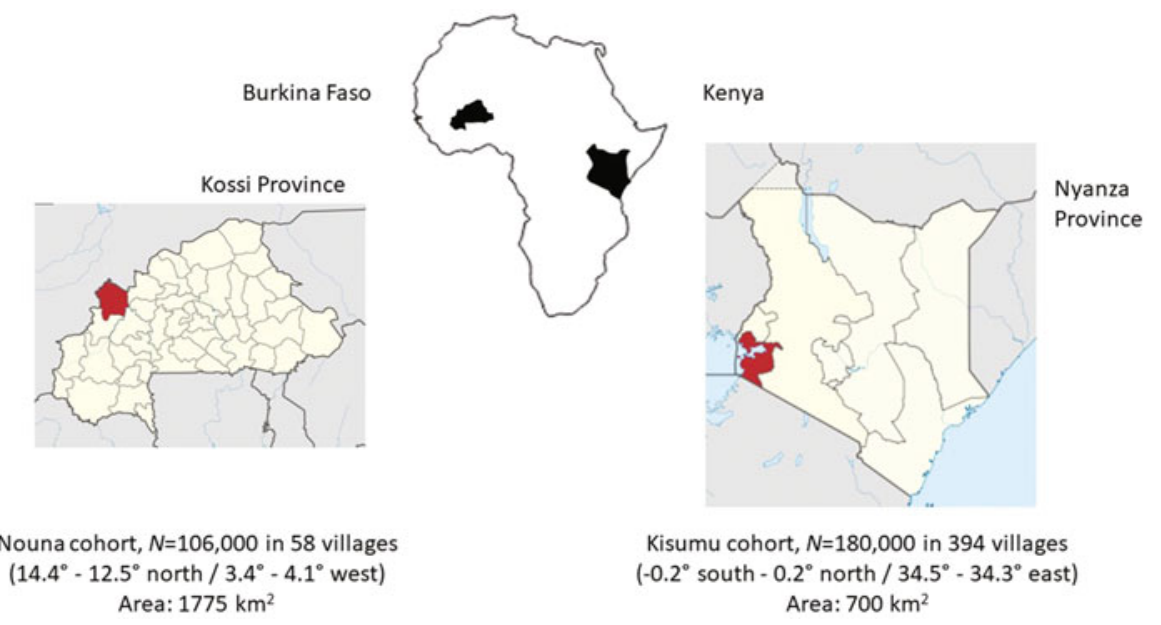

Fig. 1 The Health and Demographic Surveillance sites in Burkina Faso and Kenya

temperatures in the highlands. The inhabitants of both regions live on small-scale subsistence farming, which is complemented by fishing in the Kenyan areas close to Lake Victoria. The typical diets in both regions are based on starchy staples and legumes. According to the Living Standards Measurement Study (LSMS) by the World Bank, the share of livelihoods from subsistence farming in both areas ranges between $70 \%$ and $90 \%$ (World Bank 2017). The proportion of children with acute and chronic undernutrition tends to be higher in Kisumu than in Nouna. Both areas are holo-endemic for malaria transmission with similar prevalence among children. HIV incidence in Kisumu is three-times higher than in Nouna.

\section{Strategy 1: Agro-Biodiversification and Nutrition Intervention in Rural Burkina Faso and Rural Kenya}

\section{Background}

Climate change impacts food security through direct and indirect pathways (Myers et al. 2017), and presumably affects the spread of malaria in sub-Saharan Africa (Caminade et al. 2014; Dasgupta 2018). Increased greenhouse gas emissions, particularly $\mathrm{CO}_{2}$, reduce the contents of iron, zinc, and protein in major staple foods in this region (Myers et al. 2014; Smith and Myers 2018). This development will likely slow down the reduction of macro- and micronutrient undernutrition in the most vulnerable population group of children aged $<5$ years and their mothers (Smith and Myers 2018). As an integral part of a food-systems approach, agricultural bio-diversification seems to be a promising tool to achieve resilience against increased atmospheric $\mathrm{CO}_{2}$, improved dietary diversity, and thus, adequate micronutrient supplies and protein utilization (Constanzo and Bàrberi 2013; Olney et al. 2015). Still, the success of 
Table 1 Characteristics of the Nouna and the Kisumu Health and Demographic Surveillance (HDSS) areas

\begin{tabular}{|c|c|c|}
\hline Characteristics & Nouna, Burkina Faso & Kisumu, Kenya \\
\hline $\begin{array}{l}\text { National GDP } \\
\text { per capita in } \\
2017\end{array}$ & 670 US\$ & 1508 US\$ \\
\hline $\begin{array}{l}\text { Health care } \\
\text { facilities }\end{array}$ & $\begin{array}{l}1 \text { district hospital with surgical unit, } \\
13 \text { basic health facilities }\end{array}$ & $\begin{array}{l}36 \text { health facilities: } 1 \text { district hospital, } \\
2 \text { private hospitals, } 11 \text { health centers, } \\
\text { and } 22 \text { dispensaries }\end{array}$ \\
\hline \multirow{3}{*}{$\begin{array}{l}\text { Geographic } \\
\text { position }\end{array}$} & North-west (Boucle de Mouhoun) & West (Nyanza Province) \\
\hline & Land-locked & Partly located at Lake Victoria \\
\hline & Rural and semi-urban & Rural \\
\hline $\begin{array}{l}\text { Surveillance } \\
\text { area }\end{array}$ & $1775 \mathrm{~km}^{2}$ & $700 \mathrm{~km}^{2}$ \\
\hline Altitude & $260 \mathrm{~m}$ above sea level & $1070 \mathrm{~m}$ above sea level \\
\hline \multirow{3}{*}{$\begin{array}{l}\text { Population } \\
\text { under } \\
\text { surveillance }\end{array}$} & 115,000 individuals & 220,000 individuals \\
\hline & 14,548 households & 54,869 households \\
\hline & 58 villages & 385 villages \\
\hline $\begin{array}{l}\text { Starting of } \\
\text { HDSS }\end{array}$ & 1992 & 1990 \\
\hline $\begin{array}{l}\text { Age structure } \\
\text { of HDSS }\end{array}$ & $17 \%<5$ years of age & $13 \%<5$ years of age \\
\hline \multirow{4}{*}{$\begin{array}{l}\text { Weather/ } \\
\text { climate }\end{array}$} & Rainy season: June till October & Long rains: March till May \\
\hline & Mean annual rainfall: $800 \mathrm{~mm}$ & Short rains: October till December \\
\hline & Daily min T: $20-28^{\circ} \mathrm{C}$ & $\begin{array}{l}\text { Mean annual rainfall: } 1200- \\
1500 \mathrm{~mm}\end{array}$ \\
\hline & Daily max T: $29-37^{\circ} \mathrm{C}$ & $\mathrm{T}$ between $17{ }^{\circ} \mathrm{C}$ and $35^{\circ} \mathrm{C}$ \\
\hline $\begin{array}{l}\text { Major crops in } \\
\text { subsistence } \\
\text { agriculture }\end{array}$ & $\begin{array}{l}\text { Millet, sorghum, maize, peanuts, rice, } \\
\text { and sesame }\end{array}$ & $\begin{array}{l}\text { Maize, beans, sweet potatoes, } \\
\text { sorghum, rice, cassava }\end{array}$ \\
\hline \multirow{4}{*}{$\begin{array}{l}\text { Nutritional } \\
\text { status of } \\
\text { children } \\
<5 \text { years }\end{array}$} & $21 \%$ stunting & $30 \%$ stunting \\
\hline & $14 \%$ underweight & $20 \%$ underweight \\
\hline & $10 \%$ wasting & $6 \%$ wasting \\
\hline & $\sim 80 \%$ anemia & $\sim 50 \%$ anemia \\
\hline \multirow{2}{*}{$\begin{array}{l}\text { Malaria in } \\
\text { children } \\
<5 \text { years }\end{array}$} & $\begin{array}{l}\text { Malaria is hyper- to holoendemic, } \\
\text { peaking at the end of the rainy season }\end{array}$ & $\begin{array}{l}\text { Malaria is holoendemic with } \\
\text { transmission throughout the year }\end{array}$ \\
\hline & Prevalence: $30-50 \%$ & Prevalence: $30-50 \%$ \\
\hline \multirow[t]{2}{*}{ HIV/AIDS } & HIV rate: $0.26 / 1000$ pyrs & HIV rate: $3.09 / 1000$ pyrs \\
\hline & $\begin{array}{l}\text { Prevention of Mother-To-Child } \\
\text { Transmission (PMTCT) according to } \\
\text { WHO guidelines (coverage } 50-80 \% \text { ) }\end{array}$ & $\begin{array}{l}\text { PMTCT using Nevirapine, } \\
\text { Lamivudine, Zidovudine }\end{array}$ \\
\hline
\end{tabular}

such adaptation strategies depends on the local food supply chains (Sibhatu et al. 2015) and remains to be established for sub-Saharan Africa. In addition, a healthy nutritional status through agricultural bio-diversification may also reduce the risk of clinical malaria among young children living in endemic regions (Danquah et al. 2009). Yet, expanding the agricultural land cover bears the adverse potential of 
generating breeding sites for malaria vectors, thereby fueling parasite transmission (Janko et al. 2018).

This project addresses the potential of a household, agricultural bio-diversification, and nutrition program to improve the nutritional status and to reduce episodes of clinical malaria among young children and their mothers living in two subsistence and malaria-endemic areas of rural sub-Saharan Africa. The specific research objectives are:

(i) To establish the baseline cross-sectional associations of self-sufficient food supply and dietary habits with the status of climate-sensitive nutrients (protein, iron, zinc) among children at the age of supplementary feed introduction (6-24 months) and their mothers in rural Burkina Faso and rural Kenya.

(ii) To establish the effects of the agricultural bio-diversification and nutrition program on dietary habits, anthropometric measures of protein-energy undernutrition, micronutrient status, and the risk of clinical malaria among young children and their mothers.

(iii) To quantify the relative contributions of additional household greenspace and improved childhood nutritional status through this agricultural and nutrition intervention to malaria risk in children.

\section{Procedures}

This project will start in January 2020 and involves the scientific evaluation of an integrated agriculture and nutrition program focusing on agricultural bio-diversification to improve the status of climate-sensitive nutrients among children aged 6-59 months. For this purpose, this study will adopt a program that was successfully implemented and evaluated in other parts of rural Burkina Faso (Olney et al. 2015). The conceptual framework of this intervention program relies on three impact pathways that are depicted in Fig. 2:

- Increased production of climate-resilient horticultural crops and diversification of crops for increased consumption of these foods.

- Increased output of foods to increase income.

- Increased knowledge related to the importance of agricultural diversification (= use more indigenous plants) for the resilience of local crops and thus, food and nutrient security for healthy families, thereby increasing the adoption of optimal practices.

More specifically, the study will conduct two cluster-randomized controlled trials (cRCT), enrolling 600 households at each site with children at the age of supplementary feed introduction (6-24 months) at baseline. These households will be randomized to the control group or the intervention group. The intervention will comprise an agriculture component and a nutrition part. The agriculture component will foster agro-diversification using horticultural crops in home gardens, based on 


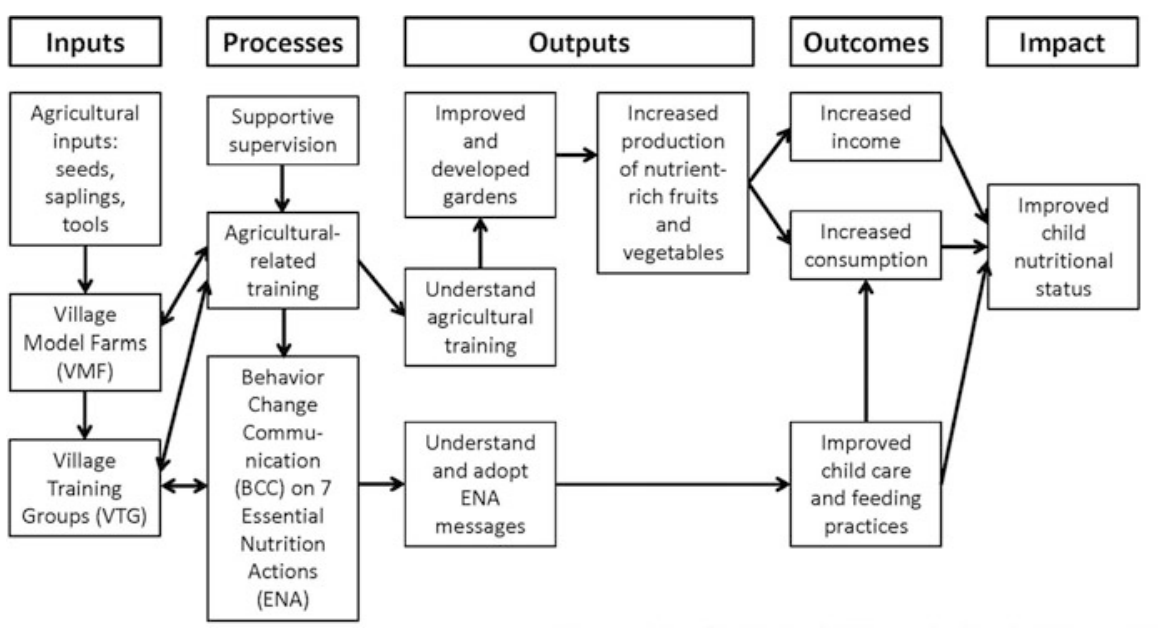

Fig. 2 Impact pathways of the integrated agricultural bio-diversification and nutrition program, modified according to Hellen Keller International's Homestead Food Production Program 2013

village model gardens and specific trainings. The nutrition component comprises regular sessions on Behavior Change Communication focusing on the seven Essential Nutrition Action (ENA) messages by the World Health Organization. After an observation period of at least 12 months, height-for-age z-scores among the enrolled children (30-48 months) will be assessed as the primary nutrition and healthoutcome. Secondary outcomes include weight-for-age z-score, weight-for-height $\mathrm{z}$-score, iron and zinc status, incl. hemoglobin concentrations $(\mathrm{Hb})$, species richness in home gardens, dietary behavior, and associated costs. The data will be analyzed on an intention-to-treat basis by random effects linear models and accounting for the cluster design. The formative research of this project has started in September 2019; the recruitment of households with young children is envisioned for the middle of 2020; and follow-up shall be completed in the first quarter of 2023.

\section{Strategy 2: Cool Roofs to Improve Human Health, Environmental and Economic Outcomes in Rural Burkina Faso}

\section{Background}

Increasing mean global temperature and extreme heat are adversely affecting people's health. Projections show that warming of $4{ }^{\circ} \mathrm{C}$ in 2100 relative to preindustrial levels in sub-Saharan Africa will result in an increase of monthly summer temperatures by $4-6{ }^{\circ} \mathrm{C}$ above present-day temperatures (Schellnhuber and Hare 2013). Even if warming is limited to within $2{ }^{\circ} \mathrm{C}$ by 2050 , adaptation costs in Africa are expected to rise to USD 35 billion/year, while warming in the range of $3.5-4{ }^{\circ} \mathrm{C}$, as projected under current emissions, will elevate adaptation costs dramatically to USD 
50 billion/year (AMCEN, UNEP, and Climate Analytics 2013). These costs highlight the need for early action.

Millions of homes in resource-poor countries are built with low-cost materials, such as corrugated metal roofing sheets, that expose occupants to high temperatures. Owing to their high expense and electricity use, technologies such as air conditioners are ill-suited in resource-poor settings to alleviate the discomfort from heat. In sub-Saharan Africa, where climate change effects on health and well-being are most severe, adaptive technologies do not yet meet the needs of populations to ease the burden from heat.

Advances in housing technologies can passively reduce indoor temperatures through increased solar reflectance and catalyzed thermal emittance (Singh et al. 2010; Howden-Chapman et al. 2007). Cool roof coatings in the form of a liquid applied membrane (LAM) are a promising, low-cost intervention to reduce indoor temperatures that may prove suitable for immediate wide-spread use across new and existing building stocks. Cool roofs that reflect direct sunlight can stay cooler than roofs that absorb sunlight. Solar reflectance (the ability to reflect the visible wavelengths of sunlight, reducing heat transfer to the surface) and thermal emittance (the ability to radiate absorbed solar energy) are the two main mechanisms through which cool roofs reduce indoor heat (Levinson et al. 2002). In clear skies, up to $95 \%$ of solar radiation is absorbed by a typical roof surface; cool roofs can substantially reduce this fraction (Dabaieh et al. 2015).

LAMs are sprayed or painted on the roof surfaces and seem to be the most suitable cool roof technology for existing homes in Nouna, Burkina Faso, because they can effectively coat surfaces with undulations or complex roofing structures such as mud bricks or corrugated tin. Different LAM types have different Solar Reflectance Indices (SRIs), which indicate the level of solar reflectivity. LAM substances can also be easily transported and are created on site.

Furthermore, LAM roofs have minimal upfront costs, zero maintenance costs, and possible co-benefits of carbon emission reduction and air quality improvements. Despite the potential for alleviating the burden of heat on the poorest households, the effect estimates on environmental and human health outcomes of cool roofs in sub-Saharan Africa remain unknown. The study site is therefore located in northwest Burkina Faso - characterized by hot dry seasons with temperatures exceeding $40{ }^{\circ} \mathrm{C}$ and a wet rainy season.

The long-term research goal is to identify viable passive housing adaptation technologies with proven health and environmental benefits to reduce the burden of heat stress in communities affected by heat in Africa. The specific objectives of this study are to:

(i) Establish the cultural acceptability of different types of LAM-based cool roofs in Nouna, Burkina Faso

(ii) Establish the effect of the cool roof on the primary endpoint heart rate as an indicator of physiological stress

(iii) Determine the effects of the cool roof on a range of secondary endpoints, including indoor temperature, indoor humidity, cardiovascular morbidity and mortality, household energy consumption, and socioeconomic outcomes 


\section{Procedures}

Within the RU, this project will start in January 2020 to test a cool-roof coating on mud-brick and tin roofs in Burkina Faso. The project will collect health, environmental, and economic outcome measures, with the primary outcomes being healthrelated, including heart rate and core body temperature.

First, a formative qualitative study will be conducted to establish the cultural acceptability of the cool roofs. Several versions of the cool roof are possible, with different appearances and different technical properties. For the successful execution of this trial and for long-term impact, it will be important to understand how best to introduce and apply the cool roof in a community and in individual homes and which color and surface material to offer. The trial will start with a formative qualitative study to elicit the local meaning of climate adaptation using the cool roof as well as perceptions of and preferences for particular cool roof colors and surface materials. Second, a cool roof mechanism study will be conducted. Before embarking on a large-scale cluster randomized controlled trial, a small-scale study of mechanisms in eight households will be conducted, which will serve two purposes. First, it will provide pilot data to optimally design the trial processes given the real-life constraints of working in rural Burkina Faso. Second, it will provide fundamental quantitative insights into the physical mechanisms of the cool roof. Most importantly, the third part will comprise a cluster-randomized controlled effectiveness trial. To date, the effects of cool roofs has not been tested in randomized controlled trials, even though such rigorous causal tests are highly feasible. In addition, there have been no studies of cool roof effectiveness in sub-Saharan Africa, the subcontinent where both the effects of climate change will be most severe and the current capacity to adapt to climate change is most limited. Thus this study will be the first cool roof cluster-randomized controlled trial (cRCT) to establish the effects of the technology on critical heat, health, and socioeconomic outcomes in 600 households. The target primary and secondary endpoints include home temperature and humidity, heart rate, core body temperature, hydration status, thermal comfort, cognition, blood pressure, and clinic and hospital utilization.

\section{Strategy 3: Index-Based Weather Insurance in Rural Burkina Faso}

\section{Background}

Emerging evidence highlights the role of climate change in the rise of climate variability and extremes around the globe (Kotir 2011). In turn, increased climate variability and extremes negatively affect the overall stability of global food systems through the decrease in food production (Rosenzweig et al. 2001). Climate changeinduced production disruptions increase rural small-holder farmers' vulnerability to undernutrition and poverty (Herrera et al. 2018). This is especially true in sub-Saharan Africa (SSA), where rural households depend mainly on rain-fed subsistence farming and consume around $70 \%$ of what they produce (Belesova et al. 2018). 
A plethora of adaptation strategies (such as crop diversification, savings, credit, informal risk-sharing arrangements at the community level) has been proposed to address the risk that climate change poses to food production (Dercon et al. 2014). Index-based weather insurance (IBWI) emerges as a promising solution vis à vis traditional crop insurance which suffers from high operational costs and premium because the indemnity payment requires strenuous verification of production losses on each farm. The verification process can be challenging in settings where farms are small and scattered, as is the case in smallholder subsistence farming in rural SSA (Leblois and Quirion 2013). In contrast, IBWI ameliorates the high operational costs and the cumbersome indemnity verification process by making indemnity payments conditional upon an objective and independently measurable weather index (e.g., rainfall or temperature index) (Skees 2008). Payment to the insured is triggered when the index falls below or above a pre-agreed threshold (Carter et al. 2014). IBWI is by no means the panacea for handling all farm losses risk faced by smallscale farmers but stands as the option with the most significant potential of "getting the big risk out of the way" (Skees 2008).

\section{Procedures}

With specific regard to the field of research, IBWI is expected to produce health gains through two distinct impact pathways that are depicted in Fig. 3. First, IBWI will expectedly improve health by improving nutritional status thanks to improved food security. Second, households who enjoy IBWI protection are anticipated to experience a lower need for saving and hence to have more disposable income for other expenses, including health service utilization, a fundamental element to maintain and restore one's health. There exist approximately 18 IBWI schemes in SSA. The majority of

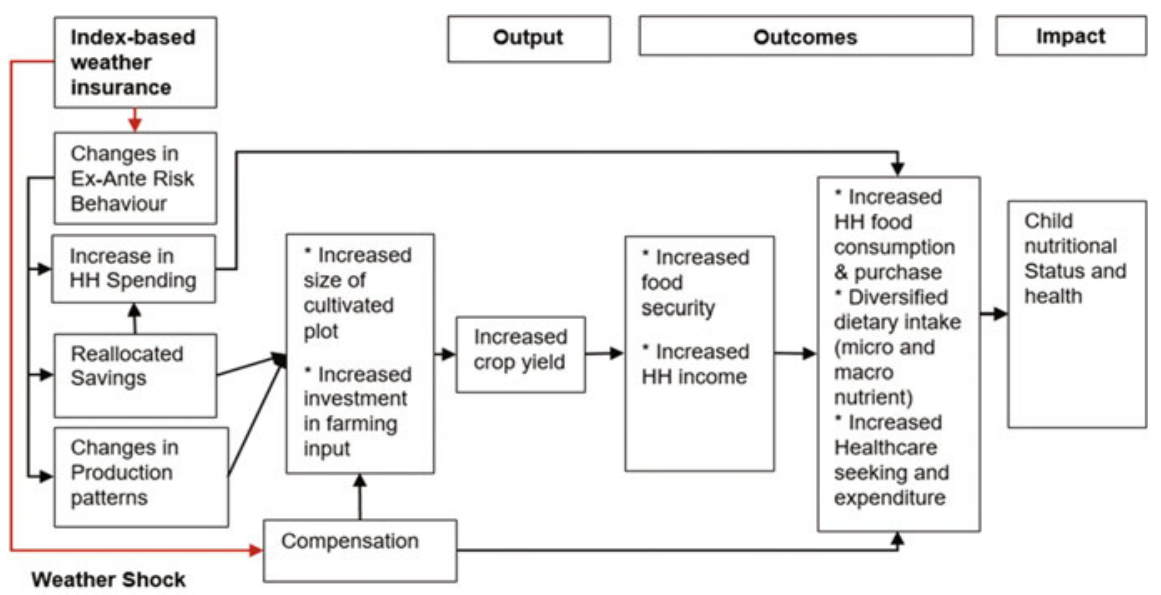

Fig. 3 Impact pathways of index-based weather insurance to improve health among smallholder subsistence farming families 
these schemes are in operation, but face multiple challenges pertaining to the demand, index design, and institutional support (Hess and Hazell 2016).

So far, the literature on IBWI has concentrated on index design problems such as basis risk and farmer characteristics that influence demand and uptake of IBWI. Less is known about how the different stakeholders (national and global policy agents, firstline implementers, and beneficiaries) interact in the design and implementation of IBWI and how this interaction might affect the success and scalability of IBWI (Duru 2016). In particular, since the literature on IBWI has been dominated by development and agricultural economics, little attention has been paid to whether concerned stakeholders conceptualize the link between insurance and health, via the causal links outlined earlier. To bridge this knowledge gap during the RU lifetime (2020-2022), a political economy analysis (PEA) (Participants at the Bellagio Workshop on Political Economy of Global Health 2015) will be conducted to understand institutional interactions of the different stakeholders involved in the design and implementation of IBWI. The PEA will be grounded in document analysis and key informant interviews, to examine how structures, institutions, and agents work towards the implementation of IBWI in Burkina Faso and Kenya. In light of recent literature highlighting polycentric governance as a driving force of policy development in LMICs, the work will also address the role of international agencies in shaping the emergence of IWBI as a climate change adaptation strategy in SSA.

\section{Strategy 4: Larviciding Against Malaria Vectors in Rural Burkina Faso}

\section{Background}

Despite intense worldwide efforts, malaria is still the world's most important and deadly tropical mosquito-borne parasitic disease. It is responsible for an estimated 435,000 deaths and 219 million disease cases (WHO 2019). Variation in climatic parameters such as temperature, rainfall amount and patterns, and humidity are known to exert influence on malaria transmission through direct influence on the life cycle of vector mosquitoes and malaria parasites (Okuneye et al. 2019).

Climate change is likely to worsen the malarial situation in many areas where malaria transmission already takes place, while, at the same time, it might grant relief in few other regions (Murdock et al. 2016). Additionally, new areas that have been traditionally malaria free, such as regions in the cooler climate and at a higher altitude, will experience an increased risk for transmission. Climate change greatly impacts and alters the El Niño cycle that is known to be associated with increased risks of some diseases transmitted by mosquitoes, such as malaria, dengue, and Rift Valley fever (Mabaso and Ndlovu 2012). In dry climates, heavy rainfall can provide good breeding conditions for the mosquitoes, while droughts in wetter areas can facilitate the formation of more mosquito breeding sites. Climate change together with an increase in resistance of vectors against insecticides and observed changes in mosquito biting behavior poses a threat to the efficacy of traditional 
vector control measures such as impregnated nets and indoor residual spraying that are currently in place (Ashley et al. 2014; Killeen et al. 2016; Thomas and Read 2016). For securing and improving current achievements in malaria vector control in a changing climate, it is more important than ever to administer control efforts in an integrated fashion, adding additional approaches, without pulling out from the already implemented ones.

Several of these shortcomings in current malaria vector control can be addressed, to varying extent, by extending control efforts to vector larvae. Other than chemicals such as DDT that were used in previous control and eradication efforts, modern vector larvae control can rely on biological larvicides such as Bacillus thuringiensis israelensis (Bti). Those are environmentally safe, target species-specific in their mode of action, and show no resistances (Becker 2000). Within the last decade, there has been generated a large body of evidence, showing that Bti-based larviciding can bring down malaria vector populations by order of magnitude and significantly reduce malaria prevalence (Tusting et al. 2013; Dambach et al. 2019). One of the main advantages of larviciding is that the vector larvae cannot elude intervention, and they can be targeted where they are concentrated and easily detectable. Dambach et al. have already shown in 2016 that Bti-based larviciding can be provided at low cost, similar to or lower than those of LLINs (Dambach et al. 2016; Maheu-Giroux and Castro 2014). Future formulations of Bti with increased residual effect and the use of new substances such as insect growth regulators are likely to reduce intervention costs further.

\section{Procedures}

The way of how larviciding is carried out depends on the used larvicide. The most common approach is to perform larviciding during the period of highest malaria transmission, which follows the period of highest vector abundance, which, in most settings, is the rainy season. In the case of $B t i$, the mostly used larvicide formulation is dissolved in water and then brought out with knapsack sprayers onto the surface of potential mosquito breeding sites such as ponds, puddles, roadside ditches but equally to smaller features such as tire marks or hoof prints that are filled with water (Fig. 4). Within several hours up to 1-day posttreatment, the larval stages of mosquitoes will have died off, which can be confirmed by visual control. Due to Bti's organic structure and sedimentation, it loses efficacy after a few days and reapplication is required (Dambach et al. 2014). In tropical climate, this retreatment interval is shorter compared to higher latitudes, and larviciding has to be carried out again every 8-10 days. Hence, depending on the duration of the rainy season, and the ambient temperature, only a few up to more than ten treatment rounds might be needed to effectively control vector populations. Besides the implementation of a meticulously followed spraying calendar, it can be beneficial to monitor larviciding success as a part of quality control, in particular during the first time of carrying out. The first step of program quality control is performed by determining the larvae kill-off rate. As a next step, 


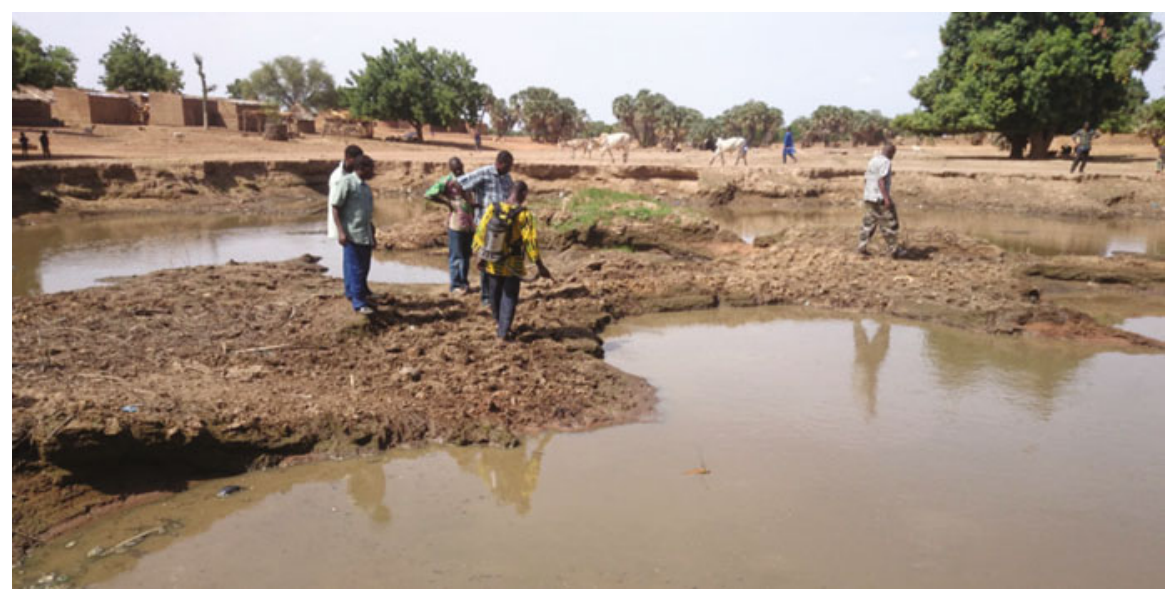

Fig. 4 Project members are spraying a stagnant body of water in Burkina Faso, in which mosquitoes develop, with the biological insecticide bti. (C) Dr. Peter Dambach, Heidelberg Institute of Global Health (HIGH), Universitaetsklinikum Heidelberg, Germany)

adult vector abundance is monitored through different types of traps and catchment techniques and compared to a pre-intervention baseline or an untreated reference area.

\section{Conclusions}

Herein, presented four viable and propagated adaptation strategies are presented to support populations in sub-Saharan Africa in their development of climateresilience. These projects are united by their careful alignment of design research, early involvement of stakeholders and decision-makers, and scientific evaluation of health outcomes as well as economic returns. Global climate change mitigation efforts are certainly needed. Still, climate change impacts on health are already discernible in rural Burkina Faso and Kenya. These transformative projects will enhance the local adaptive capacities for combatting the major health problems undernutrition, cardiovascular heat-stress, and malaria in these regions.

Acknowledgments This writing of this chapter has been supported by Prof. Rainer Sauerborn and Prof. Manuela De Allegri (Heidelberg Institute of Global Health (HIGH), Heidelberg University, Im Neuenheimer Feld 130.3 69120 Heidelberg, Germany) as well as Dr. Penelopé Vounatsou (Swiss Tropical and Public Health Institute, Socinstrasse 57 CH-4051 Basel, Switzerland).

\section{References}

AMCEN, UNEP, and Climate Analytics (2013) Africa's adaptation gap: climate-change impacts, adaptation challenges and costs for Africa. UNEP, Geneva 
Ashley EA, Dhorda M, Fairhurst RM, Amaratunga C, Lim P, Suon S, Sreng S, Anderson JM, Mao S, Sam B, Sopha C, Chuor CM, Nguon C, Sovannaroth S, Pukrittayakamee S, Jittamala P, Chotivanich K, Chutasmit K, Suchatsoonthorn C, Runcharoen R, Hien TT, Thuy-Nhien NT, Thanh NV, Phu NH, Htut Y, Han KT, Aye KH, Mokuolu OA, Olaosebikan RR, Folaranmi OO, Mayxay M, Khanthavong M, Hongvanthong B, Newton PN, Onyamboko MA, Fanello CI, Tshefu AK, Mishra N, Valecha N, Phyo AP, Nosten F, Yi P, Tripura R, Borrmann S, Bashraheil M, Peshu J, Faiz MA, Ghose A, Hossain MA, Samad R, Rahman MR, Hasan MM, Islam A, Miotto O, Amato R, MacInnis B, Stalker J, Kwiatkowski DP, Bozdech Z, Jeeyapant A, Cheah PY, Sakulthaew T, Chalk J, Intharabut B, Silamut K, Lee SJ, Vihokhern B, Kunasol C, Imwong M, Tarning J, Taylor WJ, Yeung S, Woodrow CJ, Flegg JA, Das D, Smith J, Venkatesan M, Plowe CV, Stepniewska K, Guerin PJ, Dondorp AM, Day NP, White NJ, Tracking Resistance to Artemisinin Collaboration (TRAC) (2014) Spread of artemisinin resistance in Plasmodium falciparum malaria. N Engl J Med 371:411-423

Becker N (2000) Bacterial control of vector-mosquitoes and black flies. In: Entomopathogenic bacteria: from laboratory to field application. Springer, Dordrecht, pp 383-398

Belesova K, Gasparrini A, Sié A, Sauerborn R, Wilkinson P (2018) Annual crop-yield variation, child survival, and nutrition among subsistence farmers in Burkina Faso. Am J Epidemiol 187:242-250

Bizikova L, Habtezion L, Bellali J, Diakhite M, Pinter L (2009) Vulnerability and climate change impact assessments for adaptation. Retrieved from https:/www.unenvironment.org/resources/ report/vulnerability-and-climate-change-impact-assessments-adaptation-module. Accessed 8 Nov 2018

Caminade C, Kovats S, Rocklov J, Tompkins AM, Morse AP, Colón-González FJ, Stenlund H, Martens P, Lloyd SJ (2014) Impact of climate change on global malaria distribution. P Natl Acad Sci 111:3286-3291

Carter M, De Janvry A, Sadoulet E, Sarris A (2014) Index-based weather insurance for developing countries: a review of evidence and a set of propositions for up-scaling (no. 111). Retrieved from http://www.ferdi.fr/sites/www.ferdi.fr/files/publication/fichiers/wp111_index_insurance_web_0.pdf

Constanzo A, Bàrberi P (2013) Functional agrobiodiversity and agroecosystem services in sustainable wheat production. A review. Agron Sustain Dev 34:327-348

Costello A, Abbas M, Allen A, Ball S, Bell S, Bellamy R, Friel S, Groce N, Johnson A, Kett M, Lee M, Levy C, Maslin M, McCoy D, McGuire B, Montgomery H, Napier D, Pagel C, Patel J, de Oliveira JAP, Redclift N, Rees H, Rogger D, Scott J, Stephenson J, Twigg J, Wolff J, Patterson C (2009) Managing the health effects of climate change. Lancet 373:1693-1733

Dabaieh M, Wanas O, Hegazy MA, Johansson E (2015) Reducing cooling demands in a hot dry climate: a simulation study for non-insulated passive cool roof thermal performance in residential buildings. Energ Buildings 89:142-152

Dambach P, Louis VR, Kaiser A, Ouedraogo S, Sié A, Sauerborn R, Becker N (2014) Efficacy of Bacillus thuringiensis var. israelensis against malaria mosquitoes in northwestern Burkina Faso. Parasit Vectors 7:371

Dambach P, Schleicher M, Stahl HC, Traoré I, Becker N, Kaiser A, Sié A, Sauerborn R (2016) Routine implementation costs of larviciding with Bacillus thuringiensis israelensis against malaria vectors in a district in rural Burkina Faso. Malar J 15:380

Dambach P, Baernighausen T, Traoré I, Ouedraogo S, Sié A, Sauerborn R, Becker N, Louis VR (2019) Reduction of malaria vector mosquitoes in a large-scale intervention trial in rural Burkina Faso using Bti based larval source management. Malar J 18:311

Danquah I, Dietz E, Zanger P, Reither K, Ziniel P, Bienzle U, Mockenhaupt FP (2009) Reduced efficacy of intermittent preventive treatment of malaria in malnourished children. Antimicrob Agents Chemother 53(5):1753-1759

Dasgupta S (2018) Burden of climate change on malaria mortality. Int J Hyg Envir Heal 221:782-791

Dercon S, Vargas Hill R, Clarke D, Outes-Leon I, Alemayehu ST (2014) Offering rainfall insurance to informal insurance groups: evidence from a field experiment in Ethiopia. J Dev Econ 106:132-143 
Duru MJ (2016) Too certain to invest? Public safety nets and insurance markets in Ethiopia. World Dev 78:37-51

Grace K, Davenport F, Funk C, Lerner A (2012) Child malnutrition and climate in sub-Saharan Africa: an analysis of recent trends in Kenya. Appl Geogr 35:405-413

Herrera C, Ruben R, Dijkstra G (2018) Climate variability and vulnerability to poverty in Nicaragua. J Environ Econ Policy 7:324-344

Hess U, Hazell P (2016) Innovations and emerging trends in agricultural insurance: how can we transfer natural risks out of rural livelihoods to empower and protect people? Eschborn. Retrieved from https://www.giz.de/de/downloads/giz-2016-en-innovations_and emerging trends-agricultural_insurance.pdf

Howden-Chapman P, Matheson A, Crane J (2007) Effect of insulating existing houses on health inequality: cluster randomised study. BMJ 337:334-460

IAASTD (2009) International assessment of agricultural knowledge, science and technology for development. Global report. Retrieved 7 Nov 2014, from http://apps.unep.org/publications/ pmtdocuments/-Agriculture $\% 20$ at $\% 20 \mathrm{a} \% 20$ crossroads $\% 20-\% 20$ Synthesis $\% 20$ report- $2009 \mathrm{Ag}$ riculture

IPCC (2017) Chapter XII. Human health: impact, adaptation and vulnerabilities. In: Working group II, 6th assessment report. IPCC, Geneva

Janko MM, Irish SR, Reich BJ, Peterson M, Doctor SM, Mwandagalirwa MK, Likwela JL, Tshefu AK, Meshnick SR, Emch ME (2018) The links between agriculture, Anopheles mosquitoes, and malaria risk in children younger than 5 years in the Democratic Republic of the Congo: a population-based, cross-sectional, spatial study. Lancet Planet Health 2(2):e74-e82. https://doi. org/10.1016/S2542-5196(18)30009-3

Killeen GF, Govella NJ, Lwetoijera DW, Okumu FO (2016) Most outdoor malaria transmission by behaviourally-resistant Anopheles arabiensis is mediated by mosquitoes that have previously been inside houses. Malar J 15:225

Kjellstrom T, Freyberg C, Lemke B, Otto M, Briggs D (2017) Estimating population heat exposure and impacts working people in conjunction with climate change. Int J Biometeorol 62:291-306

Kotir JH (2011) Climate change and variability in sub-Saharan Africa: a review of current and future trends and impacts on agriculture and food security. Environ Dev Sustain 13:587-605

Leblois A, Quirion P (2013) Agricultural insurances based on meteorological indices: realizations, methods and research challenges. Meteorol Appl 20:1-9

Levinson R, Akbari H, Konopacki S, Bretz S (2002) Inclusion of cool roofs in nonresidential Title 24 prescriptive requirements. Energy Policy 33:151-170

Mabaso MLH, Ndlovu NC (2012) Critical review of research literature on climate-driven malaria epidemics in sub-Saharan Africa. Public Health 126:909-919

Maheu-Giroux M, Castro MC (2014) Cost-effectiveness of larviciding for urban malaria control in Tanzania. Malar J 13:477

Murdock CC, Sternberg ED, Thomas MB (2016) Malaria transmission potential could be reduced with current and future climate change. Sci Rep 6:27771

Myers SS, Zanobetti A, Kloog I, Huybers P, Leakey AD, Bloom AJ, Carlisle E, Dietterich LH, Fitzgerald G, Hasegawa T, Holbrook NM, Nelson RL, Ottman MJ, Raboy V, Sakai H, Sartor KA, Schwartz J, Seneweera S, Tausz M, Usui Y (2014) Increasing CO2 threatens human nutrition. Nature 510(7503):139-142

Okuneye K, Eikenberry SE, Gumel AB (2019) Weather-driven malaria transmission model with gonotrophic and sporogonic cycles. J Biol Dyn 13:288-324

Olney DK, Pedehombga A, Ruel MT, Dillon A (2015) A 2-year integrated agriculture and nutrition and health behavior change communication program targeted to women in Burkina Faso reduces anemia, wasting, and diarrhea in children 3-12.9 months of age at baseline: a clusterrandomized controlled trial. J Nutr 145(6):1317-1324

Participants at the Bellagio Workshop on Political Economy of Global Health (2015) Report from Bellagio: advancing political economy of global health to understand and influence the drivers of universal health coverage. Health Syst Reform 1:20-21 
Rosenzweig C, Iglesius A, Yang XB, Epstein P, Chivian E (2001) Climate change and extreme weather events - implications for food production, plant disease, and pests. Glob Chang Hum Health 2:90-104

Schellnhuber HJ, Hare W (2013) Turn down the heat: climate extremes, regional impacts, and the case for resilience. World Bank, Washington, DC

Sibhatu KT, Krishna VV, Qaim M (2015) Production diversity and dietary diversity in smallholder farm households. Proc Natl Acad Sci U S A 112(34):10657-10662

Singh A, Syal M, Grady SC, Korkmaz S (2010) Effects of green buildings on employee health and productivity. Am J Public Health 100:1665-1668

Skees JR (2008) Challenges for use of index-based weather insurance in lower income countries. Agric Financ Rev 68:197-217. Retrieved from https://www.uky.edu/Ag/AgEcon/pubs/ resWeatherInsLIC44.pdf

Smith MR, Myers SS (2018) Impact of anthropogenic CO2 emissions on global human nutrition. Nature Climate Change 8:834-839

Thomas MB, Read AF (2016) The threat (or not) of insecticide resistance for malaria control. Proc Natl Acad Sci U S A 113:8900-8902

Tusting LS, Thwing J, Sinclair D, Fillinger U, Gimnig J, Bonner KE, Bottomley C, Lindsay SW (2013) Mosquito larval source management for controlling malaria. Cochrane Database Syst Rev 8:CD008923

Watts N, Adger WN, Agnolucci P, Blackstock J, Byass P, Cai W, Chaytor S, Colbourn T, Collins M, Cooper A, Cox PM, Depledge J, Drummond P, Ekins P, Galaz V, Grace D, Graham H, Grubb M, Haines A, Hamilton I, Hunter A, Jiang X, Li M, Kelman I, Liang L, Lott M, Lowe R, Luo Y, Mace G, Maslin M, Nilsson M, Oreszczyn T, Pye S, Quinn T, Svensdotter M, Venevsky S, Warner K, Xu B, Yang J, Yin Y, Yu C, Zhang Q, Gong P, Montgomery H, Costello A (2015) Health and climate change: policy responses to protect public health. Lancet 386:1861-1914

WHO (2014) Quantitative risk assessment of the effects of climate change on selected causes of death, 2030s and 2050s. WHO, Geneva

WHO (2019) World malaria report 2018. Retrieved from http://www.who.int/malaria/publications/ world-malaria-report-2018/en/

Woodward A, Smith K, Campbell-Lendrum D, Chadee D, Honda Y, Liu Q, Olwoch J, Revich B, Sauerborn R, Chafe Z, Haines A (2014) Climate change and health: the latest report from the IPCC. Lancet 383:1185-1189

World Bank (2017) Living Standards Measurement Study (LSMS). Retrieved from https://micro data.worldbank.org/index.php/catalog/lsms

World Bank (2018) Country profiles of Burkina Faso and Kenya. Retrieved from https://data. worldbank.org/country/

Open Access This chapter is licensed under the terms of the Creative Commons Attribution 4.0 International License (http://creativecommons.org/licenses/by/4.0/), which permits use, sharing, adaptation, distribution and reproduction in any medium or format, as long as you give appropriate credit to the original author(s) and the source, provide a link to the Creative Commons license and indicate if changes were made.

The images or other third party material in this chapter are included in the chapter's Creative Commons license, unless indicated otherwise in a credit line to the material. If material is not included in the chapter's Creative Commons license and your intended use is not permitted by statutory regulation or exceeds the permitted use, you will need to obtain permission directly from the copyright holder.

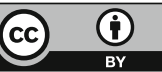

